\title{
Leadership challenges of urban institutions of higher learning, which serve a predominantly diverse and multi-cultural student population
}

\author{
Michael A. Altamirano ${ }^{1}$
}

\begin{abstract}
The topic of this research article examines the unique leadership challenges confronted by staff and faculty of higher education institutions that serve a predominantly diverse and multi-cultural student population in urban areas of the United States. Urban colleges and universities are found in the large metropolitan cities of the United States where students are from the area, as well as domestic and international. The study isolates five areas of concern that raise leadership challenges for these institutions of higher learning. Specific areas of challenge are the rising cost of tuition, retention, student preparedness for higher education, technology, and gainful employment. The exploratory research within this study was conducted primarily in the New York tri-state area. It is qualitative in nature and conclusions are based on research and observations of subjects directly affiliated with these institutions.
\end{abstract}

Key Words: Leadership, Higher Education, Cultural Assimilation, Retention, Diversity, Multi Culturalism

\section{Introduction}

This article seeks to explore factors related to current leadership issues in urban higher education. This is a study conducted among several urban communities where most, who graduate from the local public school systems are academically challenged to succeed in college. Apart from academic concerns, firsttime College students from these areas find themselves challenged to succeed because of other issues such as being from under-represented populations, various multi-cultural backgrounds, first-generation college students, or of economically challenged families.

Urban institutions find themselves challenged to navigate through issues that do not resonate in traditional and upper-tier universities throughout the United States. These issues require the leaders of urban colleges to examine reasons and solutions to help students prevail in a difficult social environment.

\section{Methodology}

The research for this article is qualitative in nature and explores one segment of higher education and related issues using a case study format. It is the intention of this article to raise awareness, questions, and ongoing topics for further research. Leadership is rooted in the ideology of influencing people to succeed and grow productively. This study seeks to shed light on the challenges of leading organizations

\footnotetext{
${ }^{1}$ Professor, King Graduate School, Monroe College, Bronx, New York, USA
} 
of higher education in an urban community. Data for this research was acquired from interviews conducted of urban higher education stakeholders such as executives, staff, faculty, and students. The scope of data is intentionally broad for the sake of acquiring a deeper understanding of issues pertaining to the article's topic. Participants of the study represented the following community of stakeholders:

- Four academic deans

- Two associate professors

- Two adjunct instructors

- Three full-time student

- Five part-time or continuing education student

Before meeting with participants, they all received correspondence outlining the topic of this study discussing contemporary/future issues regarding leadership in higher education. The selected group is directly involved within this community of urban higher education in order for information to be relevant and revealing. Participants were asked a few specific open-ended questions and were encouraged to expound liberally.

- Describe your experience working with or attending a college that serves a multi-cultural community.

- Describe the student learning experience.

- Describe the challenges for faculty teaching students from diverse multicultural backgrounds.

- Do you have any additional comments or issues regarding challenges in urban education?

- Is the urban college graduate, adequately prepared for professional life after college?

Participants were very cooperative, although some had more time than others to sit down for at least 30 minutes. There was an expectation that some or all questions would lead into other issues, and they did. After an analysis of all responses, emergent themes and issues were revealed pertaining to this topic. The findings of this study are presented in a salient manner. The emergent issues of this study are

1. The rising cost of tuition

2. Student retention

3. Student preparedness for higher education

4. Technology

5. Gainful employment

This exploration will attempt to look at these issues objectively and offer practical recommendations based on respondents and analysis. Recommendations offered in this paper are without a test for validity but are presented in hope that they will serve as themes for further research and exploration.

\section{The Rising Cost of Tuition}

The rising cost of tuition is a major source of concern for the respondents, along with other issues associated with it. There is a major concern with the enduring and sometimes un-manageable debt students acquire through education loans and repayment of federal and state grants caused by students withdrawing from courses or universities in general. According to several respondents and facts, student debt is at epidemic proportions. College graduates find themselves in the middle of an abundant but poor paying job market partly because many lack experience to go with their education. According to one 
student participant, "the loans we have to pay back are equivalent to the mortgage of a small house that we can never afford to live in."

An issue in urban cities that relates to demography is the dichotomy between the very wealthy and the very poor. For example, in New York City, most of the economically challenged residents are from African-American and Hispanic-American backgrounds. There is a direct correlation between education and levels of poverty in the world, as suggested by the economic philosopher Adam Smith in 1776 (1976). According to one respondent, Professor B, "poverty just creates more poverty. It would make sense that education is the key to rising above this. Regretfully, most of the students that do graduate from college find themselves in debt before they can even find a job within their discipline."

Another exasperating issue here is the large percentage of students who never complete their college studies and find themselves in debt with student loans and other financial assistance that they have to pay back. The United States federal government is unforgiving in this regard. The same government will guarantee loans knowing that most students will not graduate from college (Chen 2012). In large urban cities, loans are an issue, but there is also the issue of federal and state grants. These grants become the liability of the student if the student drops out in the middle of a semester or before they complete their degree (Dynarski \& Scott-Clayton, 2013).

There are various reasons why this happens and why there are concerns. One participant of this study, Dean A, adds

"One reason is poor education in financial planning. Most of our students are from impoverished backgrounds. They are from single-parent households with more than two siblings in the picture. Parents are often receiving public assistance from the government, and there is usually no financial planning learned by anyone in the household. The parents are usually in debt and students enter college with no real idea that they eventually have to pay back the money they receive for their education, by way of loans. They will often become victims of lending institutions that engage in predatory lending practices."

This quickly becomes a critical issue because student loan debt is the second largest debt in this country after home mortgages (Statista, 2018) at 1.44 trillion dollars. Respondents did offer some recommendations to help students navigate this issue

\section{Recommendations}

This is a difficult matter to resolve because tuition rates will continue to rise. In fact, the price of most things eventually rises. High tuition affects everyone, especially the economically challenged in urban populations. I believe the federal government can make a difference. According to statistics, only $7 \%$ of recent college graduates come from lower income levels, but they are the ones amassing the most debt (Mah, 2013). According to respondent, Professor A, "this is because many students enter college as a means of improving their lives, unfortunately many of those who dropout are from poor economic situations."

The current government's solution is to keep guaranteeing loans for education and federally funding schools based on performance. This means that some of the schools receiving government help are ones that need it the least. Because of poor performance, many politicians have made it their mission to block aid to for-profit colleges, which serve a predominant urban and international student population. The last 
Presidential Administration (Democratic) had been critical because of high college dropout rates. The Current presidential administration (Republican) is a supporter of for-profit colleges but many members of the opposition party are not. This is ironic because the majority of students that attend these for-profit schools are the under-represented members of society that the Democratic Party wants to represent. Policies that make the pursuit of higher education challenging, greatly hinder the ability of these students to move up the economic and social ladder.

Academic Dean C suggests a limit on government aid to schools that financially do not need it and increase aid to for-profit schools and community colleges that serve students from the inner city, urban areas, such as New York City. One dean from an [unnamed] for-profit school in the Bronx, with a student population of over $90 \%$ members of under-represented groups, describes how they cannot financially compare to an upper tier school like the University of Michigan in physical size, financial worth, and student population. According to the University of Michigan's website, $4.6 \%$ of their enrolled students are black, and less than 6\% of their enrolled students are Hispanic (Student Life Research, 2016). Compared to Barrio College [pseudonym], a for-profit college where $44 \%$ of enrolled students are Black or African American, and 36\% are of Hispanic origin (Big Future, 2016). The difference is evident and resonant. If it were not for small urban colleges, many minority students would not get a college education. This then uncovers a discussion of diversity and economic disparity where two major groups, Hispanics, and Blacks, are suffering most of the consequences.

With increased funding, smaller urban colleges can offer more financial aid and educational programs that can improve the academic achievement of their students. Student Respondent C supports the idea of more funding to smaller colleges if they also agree not to raise tuition in exchange for receiving more government aid. This would be one alternative to controlling rising tuition costs. Increased aid will not affect upper tier universities because students that are more eligible for government aid are not their target student market. At present, such an idea would need the support from government leaders. This would mean that the colleges serving these populations must produce quantifiable reports to support their cause. Many sides could benefit from such an approach, but in the end, students from urban areas will benefit greatly and have an opportunity to improve their future economic outlook.

\section{Student Retention}

Student retention refers to the concept of keeping students enrolled in college in order to improve degree completion rates. Adjunct Participant B stated, "I must admit that I never think of this topic, only when a student withdraws from one of the courses I teach. I suppose this is because I look at this on a micro level, but school officials are looking at this from a broader perspective." Retention is a major success factor because most students who enter a college or university do not graduate. The national average is $33 \%$, and in some cases like New York State, for example, the average is 21.4\% (NCHEMS, 2014). These statistics can seem alarming and this does not include the number of students who never even go to college. In some instances, the issues discussed in this study overlap, one reason students drop out of college is that of cost, and yet another reason is that many are academically unprepared.

Many other factors affect retention. According to StateUniversity.com (2018), the following are issues that contribute to rising dropout rates:

- Students enter college with a blind eye and low expectations of academic demands 
- Life situations and other outside demands

- The party animal

- Broken relationships

- Homesickness

- Job force: short-term vs. long-term

- No individual attention or guidance

As an example, most students that graduate from the New York City school system, and go to college, are commuter students. Many do not meet the academic requirements to get into upper tier universities. Therefore, their only academic alternative is to enter into the New York City University system, which has community colleges and four-year schools in every borough. This makes attending college convenient, but the college experience for many NYC residents is wrought full of obstacles. In a paper presented in 2012 at the 8th Annual Symposium at The University of Oklahoma:

"Eighteen percent of CUNY community college students support at least one child, and 76\% are from households with annual incomes below $\$ 40,000 \ldots 34 \%$ spend at least six hours per week providing care for other people and $52 \%$ work at least part-time. All of these factors are associated with a decreased likelihood of postsecondary success." (Kolenovic, Linderman, \& Mechur-Karp, 2012)

According to Student Participant A, "I can personally attest to how growing up in the New York City school system is not easy. Most students are on some kind of public assistance, and the rest have to work to make ends meet. Add to this the personal problems we all go through living here." Student Participant A eloquently describes the calamity of "personal problems" that are common among urban students who use this vague description as an excuse to not complete work or worse even, to quit school. According to Participant Professor B,

"Every time I hear this [personal problems], I am compelled to pause and take a moment to counsel the student by affirming that "personal problems" or "life issues" are constant. No one is immune, not even the instructor. Some get it and, unfortunately, some do not. The system of higher education is a machine that operates seven days a week, 24 hours a day. Many of NYC's urban students have a difficult time balancing all aspects of their life. Colleges in this area could intervene more to retain more students."

\section{Recommendations}

From a leadership perspective, student retention should start with the college administration and be supported by course instructors. It is understandable how college represents a life threshold for many individuals. It is a rite of passage for students transitioning into adulthood. Traditional institutions take a "hands-off" approach to governing students. Meaning, students orientate themselves to college and adult life with little intervention from the institution. This approach works well at larger, more traditional universities where the majority of the student population is from a middle-class economic population or higher. This is not the case for most urban students. Most come from impoverished, single parent homes. The responsibility of self-directed education can be overwhelming to students who are accustomed to a more formal structured educational system. 
Many urban colleges operate on a trimester schedule because it keeps students attending classes almost year round with the benefit for students, who stay the course, to graduate in less than four years. This is a concept that most of the for-profit schools incorporate. The City University of New York system, however, operates more traditionally and their retention rate suffers because students have a three-month break from school in the summer. Many find jobs and do not come back. Regardless of how the semesters are structured, NYC colleges could benefit from offering more personalized attention to students. They could start by keeping track of student attendance. Making this a policy and having professors incorporate it into their grading schematic will help to identify students at risk of failing and dropping out. Colleges should urge professors to reach out to students that are at risk of failing and urging these students to return to class. This would mean slightly more work, but if successful, the extra effort could result in higher retention and increased enrollment.

Many instructors might object to the idea of contacting students reminding them to attend class or inquire as to their absence from class. Participant Dean C, who is from a for-profit college states,

"I find this to be an effective way of keeping students in school. I do it often, and I encourage my professors to do so as well. I believe students genuinely appreciate the concern I have for their well-being. I do not have to do this, but I believe that reaching out to a student in need is a socially responsible act. It can be time-consuming, but I find that it enriches my spirit. Just last Sunday, I was wrapping up an online course. Students in this particular course had to complete an online final exam with an 11:00 PM deadline. I logged in at 9:00 PM to see if all the students had completed their exam. To my surprise, six had not. I proceed to call them, and they all had forgotten about the exam. Two of the students live outside the U.S.; one lives in Antigua, and the other in Jamaica. They were genuinely thankful I called them because they all would have failed if they had not taken this exam. I do not know if they would have dropped out of school if they failed but I have to believe that completing a course helps motivate an individual to complete what they started."

\section{Student Preparedness for Higher Education}

Student preparedness is a critical issue that is associated with retention. Most of the respondents in this study described, in one form or another, how most students who enter the City's community colleges or for-profit colleges must take and pass remedial courses before they can even take any credit courses. In a report published in 2017, 80\% of NYC's HS graduates need to take remedial math and English before they can enter the CUNY community colleges (Educationdive, 2017). If students do not possess minimum academic foundations before attending college, it makes sense that dropout rates will continue to rise. According to Participant Adjunct A, "I teach, based on assignment, in four colleges. Two are private institutions, one is a community college, and the other is a for-profit school. I see the difference. The two private schools have high academic standards and high retention, whereas the community college and the for-profit college have low academic standards and poor retention."

Urban students that are not prepared for the rigors of a college education are often starting in an unsettled manner, especially since most students graduating from the public education system are of Hispanic or Black origin. In an effort to emphasize this further, $51 \%$ of Caucasian graduates and $56 \%$ of AsianAmericans are academically qualified and prepared to attend college. In comparison, statistics outline 
how $85 \%$ of Hispanics and $87 \%$ of black students are not academically prepared to attend college (Otterman, 2011). The difference is evident, and it is startling. The numbers would suggest that most urban students raised in an urban environment are at an educational disadvantage. It should be the responsibility of every stakeholder in urban communities to help improve these numbers. Unfortunately, it is hard to break free from cultural restraints. One could safely suggest that Hispanic and Black parents want the best for their children, but unfortunately, they cannot provide the academic mentoring their children need because many lack familiarity with higher educational culture. According to Student Participant B,

"My educational journey was difficult. My mom and everyone I knew from her generation were blue-collar workers with no more than an eighth-grade education. The fact that I was able to graduate high school was a major accomplishment in my family's eyes. As well intended as my mom was, she could not relate nor guide me in my journey. I became a statistic shortly after graduating high school and going to college. It is not that I found college academically challenging, it is that I had too much freedom and I failed to balance school and personal life. As I failed, it became quite evident that I did not have an effective support system. I eventually found my way and went back to school."

\section{Recommendations}

Local municipalities could start a program, with local colleges, which offer incentives to students who attend urban colleges after graduating high school. The colleges can get more involved in the high schools by teaching entry-level courses that offer the students college credits. Alternatively, since $80 \%$ of local students are entering college and taking non-credit remedial courses, the colleges could offer these courses at the HS level. These courses could serve in familiarizing the student to a college expectation experience. Students will enter college with an idea of what their outlooks as students may be. When they eventually enroll into a local college, it will feel like the student is starting their second semester and that statistically improves the student's chances of staying in college (Blekic, Carpenter, \& Cao, 2017).

Another recommendation may seem radical, but there should be a way to evaluate the performance of high school guidance counselors based on the college graduation rate of students under their advisement. This would improve their involvement and the quality of advice urban students receive. Counselors could address a wide array of topics such as homesickness, and college expectations. Counselors can work off a checklist that would guide their discussions with students. An important part of the advising should be on financial counseling. To do this effectively, counselors could undergo a certification training beforehand in an effort to ensure proper college advising.

\section{Technology}

All of the respondents had comments about technology. They all agree that modern classrooms should have large monitors connected to computers to share videos and make power point presentations. Respondents from the New York City area were in agreement that colleges are starting to provide this, but most feel that the technology becomes outdated fast and institutions are slow to react. Another interesting issue regarding technology is smartphone use in classrooms. All respondents assert it is hard 
to control and some even describe how students seem to be addicted to its usage like a drug. According to Participant Professor A,

"As an instructor, I am bothered by the prevalence of smartphones. I know first-hand how distracting smartphone use is in a classroom. It is hard to police because even if you ask students to put their phones away they then take out their tablets or laptop computers. This is unlike anything I have ever experienced, I believe that technology, and how it is used is a serious problem that needs discussion."

Participant Professor B added,

"I have also been wrapping up the semester courses I teach. This is usually when students present their final presentations. Every time a group would show a video as part of their final project presentation, the video would freeze because of buffering issues. This occurred $100 \%$ of the time on three campuses. This may not seem like a big deal, but I consider this a reflection of technology and it its use at two different colleges. It is mandatory for colleges to catch up with evolving technology. I am no expert but the very least any college can provide its students, faculty, and staff is reliable technology."

Technology also brings up the issue of what can only be described as "distracted students". Modern students seem to spend most of their time using their smartphone. Apart from talking, students are using their phones now for listening to music, texting, social media, and internet access. It seems lately people walk around like zombies with their faces buried in their phones. People in the U.S.A. are all living in an age where information is immediate, social and otherwise. This issue transcends into a classroom and can potentially distract an individual from learning (Felisoni \& Godoi, 2018). Fifteen years ago, this was a non-issue. Now it has become an unpopular topic of discussion when professors bring up the subject of phone-usage to students during class. Many professors are now writing smartphone policies into their course outlines.

\section{Recommendations}

It was not long ago that modern technology in a classroom consisted of an overhead projector. In 2019, institutions of higher learning try to adapt to current technology but the technology colleges adopt become outdated quickly. According to Participant Student B, "Wi-Fi in school will often work slowly and the computers hard-wired into classrooms are often outdated and have slow internet access." Technical issues often hinder instructor and student presentations. Participant Dean C states, "I suspect the reason this is happening is that colleges do not manage this aspect of learning as other industries do. Other industries invest time and money ensuring that organizational technology is current to technological standards."

All colleges have an IT department, and these departments spend much of their time reacting to and fixing technical problems, rather than improving infrastructure. This is a fulltime endeavor. Participant Dean B adds,

"I suggest that schools look upon IT as a way of creating a competitive advantage regarding student learning. As technology evolves, technological infrastructure divisions often strain to meet the demands of students, faculty, and staff. Everyone connects to the internet in school. 
Whether it is through their smart phones, tablets, or laptops, thousands of people can connect to their campus Wi-Fi at any given time. This is not just an inner-city college issue."

Colleges have to update their technology regularly. More and more students are using their mobile devices to access the school's website and learning sites. According to an article by Noel Levitz (2013):

"In response to the rising use of mobile devices among high school students, more than one-third of four-year colleges and universities nationally now have mobile-optimized Web sites. Specifically, 39 percent of four-year public universities and 35 percent of four-year private colleges now have a Web site that is optimized for mobile browsing. The study also found these figures are set to double within the next year, as at least half of the study's respondents that are currently without mobile-optimized sites reported they were preparing to launch one by spring 2014".

Colleges are starting to understand the implications of having up-to-date technology, but a buy-in of $100 \%$ of the institutions could only happen if these institutions are committed to updating technology on a regular basis. A major issue with this solution is the cost factor. Colleges must understand that investing in technology would make their institutions more modern and marketable.

Regarding the issue brought up by the respondents of this study pertaining to the distraction of mobile devices, there is uniform concern. This is an issue of concern because it permeates into every classroom. According to a poll conducted by Zeitlinger, 176 million people reported being addicted to their mobile device (2014).

"(Teens) are not just accustomed to mobile, they expect their mobile device to handle nearly every type of task and communication," Flurry said in its report... "The same is true for college students who are noticeably avid users of messaging and gaming apps. They have just entered the workforce, are predominantly single and are likely out and about more often than older and younger segments."

One recommendation for controlling this distraction on a classroom level is to prohibit its use. This policy should be included in a professor's course outline, and the instructor should discuss the implications of its use openly at the start of every semester. An open dialogue is a great opportunity for students to voice their concerns and for instructors to reiterate the virtue of uninterrupted learning. The administration of colleges should encourage all instructors to cooperate with spreading this message. What is most important is the creation of a culture that supports technology but not to the point that it distracts in-class learning. Currently, there is a growing uncontrolled sub-culture in many higher learning environments regarding smartphone use (Targamadze \& Bulajeva, 2018). There are not enough studies on this subject but the numbers are growing. It would be interesting to understand if excessive smartphone use has an effect on cognitive learning. Technology in the classroom is essential but only if it enhances learning, not hinders it. Until more studies can demonstrate otherwise, it is best to avoid the mobile devices by creating a policy against its use in the classroom.

\section{Gainful Employment}

Gainful employment is a measure of college graduates who obtain employment after completing a degree. During the last presidential administration, the federal government measured college and university success in this category and scrutinized those institutions that performed poorly at it. This 
brought much attention to for-profit schools that serve many urban communities, charge high tuition, and have a high number of graduates who cannot find work. This was partly because the job economy at the time was poor and many of these schools were not offering the quality education offered by schools that are more traditional. In fact, a graduate sued one for-profit college in 2009 because she claimed the school did not do an adequate job of helping her find gainful employment after she graduated (CNN, 2009). It is important to note that the suit was thrown out of the judicial system because it lacked merit but not before it caught the attention of the federal government. The current presidential administration does not hold colleges accountable for gainful employment rates after graduation but with a new presidential election less than two years away, this issue may resurface again.

If we consider college education training for the future, then students should expect to be employable after graduation and in turn, the institution, which grants these degrees, will assist them in finding a job. When this happens successfully, everyone involved wins. As stewards of education, universities then fulfill a basic obligation of providing a higher education degree and the students in turn, become productive members of society through gainful employment.

According to Participant Professor A, "I believe that students will eventually fair better in life with a college degree than without one. There will always be a connection between wealth and education. I am sure it is tough to find a good paying job upon graduation." In a press briefing on July 27, 2013, William C. Dudley, Chairman and Chief Executive Officer of the Federal Reserve Bank of New York, said the following:

"It is important for us to undertake this kind of analysis because, as we'll show, newly minted graduates always take some time to transition into the labor market and find jobs that utilize their education. And young people with college degrees still fare far better than those without. At the same time, with the sluggish jobs recovery from the recession, it's clear that the transition of recent graduates into the labor market is taking longer, and they've experienced higher unemployment and higher underemployment than in years past. Still, while times have gotten tougher for recent graduates, we shouldn't be too hasty in concluding that getting a college education won't help people find good jobs." (2013)

\section{Recommendations}

One recommendation to solving the gainful employment issue is to improve the career services department of most colleges. This would help greatly but the classroom experience can also help gainful employment. Colleges in the urban communities can benefit greatly from hiring instructors that have similar backgrounds or can culturally relate to their students. Multiethnic differences are a cultural and communication gap in the higher education landscape (Magaldi, Conway, \& Trub, 2018). Students are already entering urban colleges with the statistical likelihood they will fail. If they do graduate, they do so without any experience or skills, just an education. The conscience hiring of instructors from similar backgrounds could serve as positive role models for students. They can relate to these instructors' personal experience, and in turn, these instructors serve as influential role models to their students. Student participant B described the experience meeting an accomplished instructor from a similar area of Jersey City, New Jersey than him. The participant gave an account of how meeting an instructor with

a similar background was inspiring and made the course interesting. Participant Professor C added, "I 
am from the same neighborhood many of my students are from. I can relate to their unique challenges." The same participant appeared to get very emotional during the interview and went on to say,

"In the fourteen years, I have been serving as an adjunct, I have advised five former students through graduate school, career, and eventually in the role of graduate instructor. Four are from the New York City area and one is from Ghana. they all entered college with much uncertainty and have found success through education, commitment, and hard work. I connect with them often, and we discuss all issues relating to economic background, residential location, and education. We agree that students need role models they can relate to and trust. When I hear "I can't," I see an opportunity to look students in the eye and say, "yes you can." This resonates and drives home the point of believing in oneself."

It makes sense to hire more instructors who share similar backgrounds as most of their students. Instructors should be willing to teach life lessons as well as curriculum driven lessons (Loera, Rueda, \& Oh, 2015). Instructors should be able to share their own experience in order to give students an idea of what they can expect in the real world. Students benefit from these lessons as they move into the job market. Colleges benefit by graduating committed alumni that are able to find gainful employment and career success because of lessons learned inside a classroom taught by instructors that helped students believe in their abilities.

Another further recommendation is to revisit the career service office, which exists in all colleges, and consider a different way of conducting business. Like technology, the employment landscape has changed dramatically in the last twenty years. Employers, more than ever, currently seek leadership attributes in potential candidates. In an article by Laura M. Colarusso (2014), she articulates how some universities are offering programs that help fill the skills gap between education and gainful employment.

"You can sit in a room and learn economic theory from a professor or a textbook, but at the end of the day, it's still just theory,' said Wei, who now works as a data analyst, 'they don't teach you how to apply that theory. The Tuck School of Business at Dartmouth offers a similar month long program in the summers for $\$ 10,000$ and is expanding it to December. Harvard Business School just started a $\$ 1,500$ online course to teach undergraduates elsewhere 'the fundamentals of business thinking."'

These are great ideas, unfortunately because of financial concerns; these programs do not target many urban students.

A recommendation here would be that career service offices start developing programs to offer additional job skills training, free of charge to students graduating from their institutions. A seminar on leadership would certainly help students bridge this gap. This seminar should include orientation on the following:

- Emotional intelligence - that includes communication, verbal, written and listening

- Technological - cannot assume all students are computer savvy because they know social media. Must make sure they know computer technology for business

- Change management - This is a concept many new employees have trouble grasping

- Ethics - a good review of this is necessary and important is always useful

- Conflict resolution - conflict in any business is often inevitable. Understand the causes of conflict and ways to resolve is important to any professional 
Offering seminars, free of charge, could potentially be self-sustaining while creating more employment opportunities for graduates. This measurable success would be recognized by the Unites States Department of Education, and qualify the institutions for more government aid, as outlined by the current government administration.

Counsellors, in most career offices, should have the skills to facilitate such a seminar but if not, there is a pool of deans and instructors to pull from. In fact, academic deans should be involved in the creation of such seminars to ensure academic uniformity in concepts taught. In the end, gainful employment is an issue that affects the actual students most of all. Colleges have an ethical obligation to offer career assistance. These offices cannot continue to run as they did 25 years ago. Businesses have evolved, so should the potential job applicant and the offices that assist them

\section{Conclusion}

Higher education is a highly imperfect industry shaped with perfect intentions. Urban higher education is challenging because of the complex nature of the students and the industry's organizational processes. The issues uncovered in this research serve to add to the discussion on this topic, while proposing ideas for further research.

Leadership carries with it many challenges. For institutions immersed within urban communities, there is the challenge of bridging the gaps of social-culture, communication, technology, and economics. Doing so requires a heightened sense of familiarity and wisdom regarding the population of students they serve. The barriers that exist for these students are systematically created by systems that shape behavior from early childhood to adulthood. There is opportunity for leaders to transform the lives of an underrepresented community of students that are deserving of a chance to succeed. Ideally, institutions of higher learning exist to educate and serve. This service should resound for a lifetime. Students from urban communities are then given the opportunity to lead, give back, and model successful behavior that has the ability to change the paradigm of under-representation.

\section{References}

The College Board. (2016). Big Future. Retrieved from https://bigfuture.collegeboard.org/collegeuniversity-search/monroe-college\#

Blekic, M., Carpenter, R., \& Cao, Y. (2017). Continuing and Transfer Students: Exploring Retention and Second-Year Success. Journal of College Student Retention:Research, Theory, and Practice.

Alumna Sues College Because She Hasn't Found a Job. CNN.com. (2009). Retrieved from http://www.cnn.com/2009/us/08/03/new.york.jobless.graduate/

Colarusso, L. M. (2014, July 8). Students are Paying Extra for Business Skills They Say They Haven't Learned on Campus. The Hechinger Report. Retrieved from http://hechingerreport.org/content/students-paying-extra-business-skills-say-havent- learnedcampus_16334/

Dudley, W. C. (2013, June 27). Are Recent College Graduates Finding Good Jobs? Federal Reserve Bank of New York. Retrieved https://www.newyorkfed.org/newsevents/speeches/2013/dud130627.html 
Leadership challenges of urban institutions of higher learning, which serve a predominantly diverse and multicultural student population, Michael A. Altamirano

Dynarski, S., \& Scott-Clayton, J. (2013). Financial Aid Policy: Lessons from Research. National Bureau of Economic Research, 23(1), 67-91.

CUNY Leaders: 80\% of Freshmen Need Remediation, Fewer than Half Return. (2017). Educationdive. Retrieved from https://www.educationdive.com/news/cuny-leaders-80-of-freshmen-needremediation-fewer-than-half-return/438579/

Felisoni, D. D., \& Godoi, A. S. (2018, February). Cell Phone Usage And Academic Performance: An Experiment. Journal of Computers and Education. Journal of Computers and Education, 117, 175187.

Kolenovic, Z., Linderman, D., \& Karp, M. M. (2012). Improving Student Retention and Graduation via Comprehensive Supports: Two- and Three-Year Outcomes from CUNYs Accelerated Study in Associate Programs (ASAP). Community College Review, 41(4), 271-291. Retrieved from http://www1.cuny.edu/sites/asap/wp-

content/uploads/sites/8/2015/04/kolenovic_linderman_karp_ccr_2013_improving_student_outco mes_print_version.pdf

Levitz, R. N. (2013). College E-Recruiting Strategies: Is Your Campus Keeping up With Technology? Education Insights. Retrieved from https://www.ruffalonl.com/college-e-recruiting-strategies/

Loera, G., Rueda, R., \& Oh, Y. J. (2018). Learning and Motivational Characteristics of Urban Latino High School Youth. Journal of Urban Education, 53(7), 875-898.

Magaldi, D., Conway, T., \& Trub, L. (2018). I Am Here for a Reason: Minority Teachers Bridging Many Divides in Urban Education. Journal of Race Ethnicity and Education, 21(3), 306-318.

Mah, J. (2013). Looking for Solutions to Rising Education Costs. The State Press, Arizona State University. Retrieved from http://www.statepress.com/2013/10/20/looking-for-solutions-to-risingeducation-costs/

NCHEMS Information Center for Higher Education Policy Making. (2014). Retrieved from http://www.higheredinfo.org/dbrowser/index.php?measure $=92$

Otterman, S. (2011, June 14). College-Readiness Low Among State Graduates, Data Show. The New York Times. Retrieved from https://www.nytimes.com/2011/06/15/nyregion/37-of-new-yorkgraduates-meet-college-readiness-standard.html

Smith, A. (1976). An Inquiry into the Nature and Causes of the Wealth of Nations. Oxford, United Kingdom: Oxford University Press.

StateUniversity.Com (2018, December 4). 7 Reasons Why Students Drop Out of College. U.S. University Directory.

Statista (2018). Value of Debt Owned by Consumers in the United States as of September 2018. Statista: The Statistics Portal. Retrieved from https://www.statista.com/statistics/500814/debt-owned-byconsumers-usa-by-type/

Student Life Research (2016). Student Life. The University of Michigan. Retrieved from https://docs.google.com/spreadsheets/d/1mcfum3duzsdijhbcz-

_my0apsgn1de1unecx7r7qi8k/edit\#gid=1565511833

Targamadze, V., \& Bulajeva, T. (2018). New Generation Subculture Formation on the Crossing of Real and Virtual Space. Journal of Multicultural Studies, 39-56. 
Leadership challenges of urban institutions of higher learning, which serve a predominantly diverse and multicultural student population, Michael A. Altamirano

Zeitlinger, R. (2014, April 26). Poll: Are you Addicted to Your Mobile Device? The Jersey Journal. Retrieved from https://www.nj.com/hudson/voices/2014/04/poll_are_you_addicted_to_your.html 